\title{
PENGARUH DUKUNGAN SOSIAL SEBAGAI MODERATOR KETIDAKSEIMBANGAN KEHIDUPAN-KERJA DAN KETERIKATAN KERJA PERAWAT
}

\author{
Rosyeni Chan ${ }^{1}$ Zamralita $^{2}$, Rita Markus Idulfilastri ${ }^{3}$ \\ ${ }^{1}$ Program Studi Magister Psikologi, Universitas Tarumanagara, Jakarta \\ Email: rosyeni.717171026@stu.untar.ac.id \\ ${ }^{2}$ Fakultas Psikologi, Universitas Tarumanagara, Jakarta \\ Email: zamralita@fpsi.untar.ac.id \\ ${ }^{3}$ Fakultas Psikologi, Universitas Tarumanagara, Jakarta \\ Email: ritamarkus@fpsi.untar.ac.id
}

Masuk : 21-04-2020, revisi: 21-10-2020, diterima untuk diterbitkan : 31-10-2020

\begin{abstract}
This study discussed about work engagement of nurses who experienced work-life imbalance and how the support from supervisor, coworker, organization, and family impacting it. This study aims to examined the moderating effect of social support in relation of work-life imbalance and nurses' engagement and also evaluate the role of social support's dimensions. A total of 120 nurses with a diploma in nursing participated in this study. They were working in nursing activities and lived with family as daily basis. The study was using adapted form of UWES-9, Industrial Society's Work-Life, and CESS questionnaires. Measurement being done with Structural Equation Modeling (SEM) method and measurement model using Confirmatory Factor Analysis (CFA) with Lisrel 10.0. Structural model testing showed that work-life imbalance significantly correlated with work engagement $\left(r=-0.24\right.$, normed $\chi^{2}<2.00$, RMSEA $<0.05$ ), and no significant moderating effect of social support was found. Only support from coworker moderated the work-life imbalance and work engagement of nurses $\left(r=0.20\right.$, normed $\left.\chi^{2}<2.00, R M S E A<0.05\right)$, and neither support from supervisor, organization, and family show any significant correlations as moderating variables. As conclusion, hypotheses was tested and confirmed. The findings showed work-life imbalance negatively correlated with work engagement, and support from coworker can help buffer the impact of imbalanced work-life condition on nurses' engagement. The other dimensions of social support show no significant correlations.
\end{abstract}

Keywords: work-life imbalance, work engagement, social support, nurse

\begin{abstract}
ABSTRAK
Perawat dalam melaksanakan tugasnya rentan menghadapi kondisi ketidakseimbangan kerja yang dapat mempengaruhi keterikatan kerja mereka. Untuk mengatasi pengaruh tersebut diperlukan sumber daya seperti dukungan sosial dari atasan, rekan kerja, organisasi, dan keluarga perawat yang dapat memberi dukungan pekerjaan bagi perawat. Tujuan dari penelitian adalah untuk melihat peranan dukungan sosial dan masing-masing dimensinya sebagai moderator pada pengaruh ketidakseimbangan kehidupan kerja terhadap keterikatan kerja perawat. Partisipan penelitian adalah perawat $(\mathrm{N}=120)$ yang sedang aktif bekerja di bidang keperawatan dan berstatus tinggal dengan keluarga. Data diperoleh dengan kuesioner UWES-9, Industrial Society's Work-Life, dan CESS yang telah diadaptasi. Pengolahan data menggunakan metode SEM dan pengujian model pengukuran menggunakan Confirmatory Factor Analysis (CFA) dengan bantuan program Lisrel versi 10.0. Hasil pengujian structural model menunjukkan bahwa ketidakseimbangan kehidupan kerja berkorelasi signifikan terhadap keterikatan kerja $(r=-0.24$, normed $\chi^{2}<2.00$, RMSEA $<0.05$ ), sementara peran dukungan sosial sebagai variabel moderator tidak signifikan berkorelasi. Hanya satu dimensi dukungan sosial, yaitu dimensi coworker, secara signifikan berperan sebagai moderator $\left(\mathrm{r}=0.20\right.$, normed $\chi^{2}<2.00$, RMSEA $\left.<0.05\right)$, sementara dimensi supervisor, organization, dan family tidak menunjukkan korelasi yang signifikan sebagai moderator. Kesimpulan dari penelitian ini adalah ketidakseimbangan kehidupan-kerja berpengaruh negatif terhadap keterikatan kerja perawat, dan hanya dukungan sosial dari rekan kerja yang dapat berperan sebagai moderator dalam hubungan tersebut. Sementara dukungan sosial dari atasan, organisasi, dan keluarga tidak berperan sebagai moderator antara ketidakseimbangan kehidupan-kerja dan keterikatan kerja pada perawat.
\end{abstract}

Kata Kunci: ketidakseimbangan kehidupan-kerja, keterikatan kerja, dukungan sosial, perawat 


\section{PENDAHULUAN}

Pekerjaan di dunia kesehatan merupakan pekerjaan dengan tingkat stres yang tinggi. Tenaga kesehatan seperti dokter dan perawat, dituntut untuk membuat keputusan secara cepat, menangani pasien berkondisi kritis, dan melakukan interaksi dengan tuntutan emosi yang tinggi dengan pasien dan atau keluarga pasien (Ng, 2017; Montgomery, 2015; Hakanen, 2005). Dokter memiliki tugas utama dalam pemeriksaan dan melakukan tindakan medis, sementara tugas kerja perawat yang terutama adalah merawat pasien secara intens sesuai instruksi dari dokter. Tugas kerja tersebut menuntut perawat perlu lebih sering melakukan interaksi secara rutin dan jangka panjang dengan pasien dan keluarganya, yang membuat tuntutan kerja mereka berbeda dari tenaga kesehatan lainnya (Montgomery, 2015; Ng, 2017).

Di luar dari pekerjaan keperawatan sendiri, perawat juga merasakan tuntutan dari peraturan kerja perusahaan. Tuntutan tersebut di antaranya adalah jam kerja perawat yang panjang atau kerja lembur, kerja shift, kerja dalam jadwal kerja yang tidak teratur, penempatan karyawan yang kurang adekuat, tingginya beban kerja, dan tekanan pekerjaan ( $\mathrm{Ng}, 2017)$. Berdasarkan wawancara awal yang dilakukan oleh peneliti, peraturan kerja perawat di klinik atau rumah sakit di Indonesia sering menyebabkan perawat di lapangan harus bekerja dengan jam kerja yang tidak teratur, bekerja dalam shift yang panjang, bersiaga untuk menerima panggilan cito di luar jam kerja, bekerja lembur, maupun bekerja di hari libur. Selain itu, tuntutan untuk mengerjakan pekerjaan administratif atau pekerjaan di luar tindakan keperawatan lainnya juga terhitung banyak. Fenomena tersebut mengindikasikan bahwa perawat cenderung lebih rentan mengalami permasalahan terkait keseimbangan kehidupan kerja, variasi tugas yang banyak, dan beban kerja yang tinggi. Bila tuntutan-tuntutan akibat aturan kerja ini dianggap sebagai kondisi yang mengganggu (hindrance demands), juga akan memengaruhi kondisi emosi dan fisik perawat (Bakker, 2011).

Penelitian di beberapa organisasi menyatakan bahwa tuntutan pekerjaan yang tinggi mengakibatkan kelelahan mental dan fisik karyawan (Bakker, 2011). Ketika pekerjaan cenderung menyita banyak waktu maka akan mengganggu ritme kehidupan pribadi perawat. Kondisi ini memunculkan suatu keadaan tidak harmonis antara keseharian dan pekerjaan perawat, atau yang disebut juga sebagai ketidakseimbangan kehidupan kerja (Dex \& Bond, 2005). Ketidakseimbangan kehidupan kerja merupakan kondisi terjadinya konflik antar peran dimana saling terdapat ketidaksesuaian tekanan antara peran pekerjaan dan peran keluarga dalam hal-hal tertentu (Greenhaus, 2011; Greenhause \& Beutell dalam Virga, 2015).Kondisi ketidakseimbangan kehidupan-kerja muncul ketika individu tidak dapat mencapai komitmen terhadap pekerjaan dan kehidupan pribadinya akibat dari waktu kerja yang panjang, intensitas kerja yang tinggi, dan atau adanya tekanan. Kondisi demikian dapat dinilai sebagai stressor pekerjaan dan dikonsepkan sebagai tuntutan yang dialami individu di pekerjaan (Bakker, 2014).

Kondisi tuntutan pekerjaan yang tinggi dapat memunculkan permasalahan yang lebih lanjut bagi perawat, seperti meningkatnya tingkat stress, burnout, dan turnover, dan lebih jauh lagi akan menimbulkan dampak pada kinerja maupun kesejahteraan subjektif tenaga kesehatan (Pratiwi, 2017; Runtu \& Hamel, 2018; Siwu, 2018). Berdasarkan hasil wawancara, perawat yang kurang mampu mengatasi tuntutan-tututan pekerjaan akan menunjukkan performa kerja yang lebih menurun dibanding perawat lainnya, seperti menjadi lebih malas, lambat, dan kurang bersemangat dalam bekerja. Perawat-perawat tersebut juga menjadi lebih sering mengeluh kelelahan, menunjukkan penolakan saat diminta untuk lembur atau bekerja longshift, dan sangat perhitungan mengenai kuantitas jam kerja serta beban kerja yang dilimpahkan kepadanya. Namun tetap terdapat perawat-perawat yang mampu mengatasi tuntutan pekerjaan ini dengan 
baik. Dalam kondisi tuntutan pekerjaan yang tinggi, perawat-perawat tersebut menunjukkan perilaku seperti tetap bersemangat bekerja, ceria, antusias, gesit, serta sabar dalam menangani pasien. Mereka juga menunjukkan kesediaan untuk membantu pekerjaan rekan perawat yang sedang kewalahan dan berupaya meningkatkan motivasi kerja rekan perawat lainnya. Kondisi perawat yang lebih positif tersebut menggambarkan kondisi keterlibatan yang lebih kuat dalam pekerjaannya dibanding perawat yang kurang mampu mengatasi tuntutan pekerjaannya. Keterlibatan yang dialami tenaga perawat terhadap pekerjaannya merupakan gambaran dari keterikatan kerja yang tinggi.

Keterikatan kerja merupakan kondisi mental terkait pekerjaan yang memunculkan perasaan positif dan terpenuhi, yang dicirikan oleh adanya semangat, dedikasi, dan absorpsi pada saat bekerja (Schaufeli \& Bakker, 2006). Semangat (vigor) menggambarkan derajat kekuatan energi dan mental karyawan selama bekerja untuk berusaha sekuat tenaga dalam menyelesaikan pekerjaan dan tekun dalam menghadapi kesulitan kerja. Dedikasi (dedication) menggambarkan derajat kekuatan perasaan keterlibatan dalam suatu pekerjaan sehingga karyawan merasa bermakna, antusias, bangga, terinspirasi dan tertantang pada saat bekerja. Absorpsi (absorption) menggambarkan derajat keterlibatan karyawan pada saat bekerja hingga sulit untuk memisahkan diri dengan pekerjaan, selalu penuh konsentrasi dan serius terhadap suatu pekerjaan. Karyawan yang memiliki absorpsi yang tinggi akan merasa senang saat bekerja dengan sungguh-sungguh, merasakan perasaan terlarut saat bekerja, dan merasa menikmati ketika sedang mengerjakan pekerjaannya.

Karyawan yang memiliki ikatan secara psikologis dengan pekerjaannya akan menunjukkan keterikatan yang lebih kuat dalam pekerjaan. Hal ini diperkuat oleh Bakker (2014) bahwa keterikatan kerja dapat menjadi kondisi yang menyenangkan dengan konsekuensi yang positif, seperti peningkatan performa kerja, merasakan emosi positif, kesehatan yang lebih baik, dan lain-lain.Mulai banyak rumah sakit dan klinik yang sudah lebih memperhatikan kesejahteraan subjektif perawat melalui peningkatan keterikatan kerja tersebut (Gabel-Shemueli, 2012; Montgomery, 2014). Namun ketika perawat memandang tuntutan dari pekerjaan yang dijalaninya sebagai hal yang mengganggu, hal ini berdampak negatif terhadap semangat kerja dan perasaan terlibat perawat terhadap pekerjaannya, serta dapat menurunkan keterikatan kerja perawat (Gabel-Schemueli, 2012; Montgomery, 2015; Hu, 2016).

Banyak penelitian yang menunjukkan bahwa perawat memandang tuntutan dari pekerjaan yang dijalaninya sebagai hal yang mengganggu, hal ini berdampak negatif terhadap semangat kerja dan perasaan terlibat perawat terhadap pekerjaannya, serta dapat menurunkan keterikatan kerja perawat. Pada saat karyawan memiliki tuntutan pekerjaan yang tinggi, karyawan cenderung tidak bersemangat untuk bekerja dan lebih sulit mempersepsikan keterikatan yang tinggi terhadap pekerjaannya (Gabel-Shemueli, 2012; Montgomery, 2015; Hu, 2016). Namun penelitian dari Virga (2015) menunjukkan bahwa tuntutan pekerjaan juga dapat dipersepsi sebagai hal yang menantang dan dapat meningkatkan keterikatan kerja karyawan. Kondisi ketidakseimbangan kehidupan kerja dapat diatasi dengan baik sehingga keterikatan kerja karyawan dapat tetap tinggi pada saat perawat memiliki job resource atau personal resource yang tinggi pula.

Penelitian Gabel-Shemueli (2012), Montgomery (2015), dan Hu (2016) memosisikan dukungan pekerjaan sebagai moderator antara ketidakseimbangan kehidupan-kerja terhadap keterikatan kerja perawat, sementara penelitian Virga (2015) memosisikan ketidakseimbangan kehidupankerja sebagai moderator antara dukungan pekerjaan dan keterikatan kerja. Namun kondisi tingginya personal resource dan job resource seringkali tidak dapat tercapai di klinik atau rumah 
sakit di Indonesia karena keterbatasan sumber daya yang ada dan tingginya kebutuhan pasien akan perawatan yang murah dan cepat dari rumah sakit.

Salah satu intervensi yang dapat dilakukan perusahaan adalah meningkatkan dukungan pekerjaan (Bakker, 2014). Dari hasil wawancara yang dilakukan, alasan karyawan dapat tetap bersemangat dan berdedikasi untuk bekerja meskipun dalam kondisi kelelahan dan banyak tuntutan salah satunya adalah ketika terdapat dukungan dari rekan kerja dan atasannya. Perawat merasa lebih bersemangat bekerja dalam lingkungan yang saling mendukung, ada kemauan untuk saling membantu pekerjaan rekan perawat lainnya, ada kekompakan dalam bekerja, dan terdapat atasan yang memotivasi dan memberikan dukungan.

Dukungan sosial di tempat kerja yang dialami perawat akan berbeda dengan dukungan sosial di keseharian. Dukungan sosial dapat dikaji secara multidimensi (Boyar, 2014). Dukungan sosial memiliki ranah yang spesifik (misalnya ranah pekerjaan atau keluarga) dan muncul dari sumbersumber yang berbeda, di dalamnya meliputi tipe yang berbeda, arahnya dapat di dalam satu ranah yang sama (between-domain support) atau antar ranah (across-domain support). Dukungan di ranah pekerjaan dapat berupa dukungan dari atasan, dukungan dari rekan kerja, dan dukungan dari organisasi tempat bekerja. Sementara dukungan di ranah keluarga atau ranah pribadi dapat berbentuk bantuan dan dukungan dari anggota keluarga, atau dari teman dekat, sahabat, dan figur-figur signifikan lainnya.

Dukungan sosial sebagai salah satu bentuk dukungan pekerjaan memiliki peran penting dalam proses motivasional (Bakker, 2014). Jika tingginya kondisi ketidakseimbangan kehidupan kerja dapat mengakibatkan turunnya derajat keterikatan kerja perawat, dengan adanya dukungan sosial yang tinggi terhadap pekerjaan perawat diharapkan dapat memotivasi dan memiliki efek reduksi terhadap pengaruh negatif ketidakseimbangan kehidupan kerja pada keterikatan kerja perawat. Dukungan sosial dapat memoderasi hubungan negatif antara tuntutan kerja dan keterikatan kerja sehingga perawat yang mengalami ketidakseimbangan kehidupan kerja masih dapat mempersepsikan keterikatan kerja yang tinggi di tempat kerjanya. Hal ini sejalan dengan model tuntutan-dukungan pekerjaan (Bakker, 2014) dimana tuntutan pekerjaan yang tinggi dapat dikurangi efek negatifnya terhadap keterikatan kerja karyawan melalui peningkatan dukungan pekerjaan yang dimilikinya.

Oleh karena itu, peneliti tertarik untuk menguji pengaruh dari tuntutan pekerjaan berupa ketidakseimbangan kehidupan kerja terhadap keterikatan kerja perawat ketika dipengaruhi oleh dukungan sosial sebagai aspek dukungan pekerjaan. Peneliti ingin menguji peran moderasi dari dukungan sosial dalam meningkatkan keterikatan kerja perawat, terutama saat perawat mengalami kondisi waktu kerja yang dipersepsi mengganggu kehidupan pribadinya. Melalui penelitian ini, diharapkan dapat diketahui gambaran hubungan antara tuntutan ketidakseimbangan kehidupan kerja, keterikatan kerja, dan dukungan sosial sebagai moderator pada profesi perawat.

\section{METODE PENELITIAN}

\section{Partisipan penelitian}

Populasi sasaran dalam penelitian ini adalah perawat yang sedang aktif bekerja. Berdasarkan Pusat Data dan Informasi Kementerian Kesehatan RI tahun 2017, jumlah perawat di Indonesia adalah 206.876 orang. Karakteristik partisipan yang ditentukan dalam penelitian ini adalah lulusan dari diploma keperawatan dan atau profesi ners, aktif bekerja sebagai perawat fungsional di rumah sakit atau klinik di Indonesia, dan tinggal dengan keluarga. Teknik yang digunakan 
untuk menentukan sampel dalam penelitian ini adalah dengan purposive sampling dengan jumlah sampel minimum yang disarankan adalah sebanyak lima kali dari jumlah indikator atau observed variable (Bentler \& Chou dalam Widhiarso, 2010). Partisipan penelitian ini berjumlah 120 orang dengan mayoritas perempuan sebanyak 71 orang dan laki-laki sebanyak 49 orang. Partisipan berada dalam rentang usia 21 tahun hingga 53 tahun.

\section{Prosedur penelitian}

Kuesioner diadaptasi oleh tim peneliti dan satu orang penerjemah berlatar pendidikan magister ilmu linguistik dari kuesioner berbahasa Inggris. Kuesioner diuji coba pada 2 orang perawat untuk penyesuaian penggunaan istilah, kemudian dilakukan revisi sesuai umpan balik pada saat uji coba. Pengumpulan data penelitian dilakukan dengan membagikan kuesioner kepada perawat-perawat di Indonesia, via online dan via paper and pencil test di institusi. Terlebih dahulu mengajukan surat izin penelitian kepada beberapa perusahaan dan rumah sakit besar di DKI Jakarta. Dari 3 surat pengajuan yang dikirimkan, terdapat 1 perusahaan yang memberikan izin bagi peneliti untuk melakukan pengambilan data. Pengambilan data di perusahaan tersebut dilakukan dengan metode pencil and paper test pada tanggal 18 November dan 25 November 2018. Jumlah partisipan yang hadir adalah 14 perawat di tanggal 18 November 2018 dan 22 orang di tanggal 25 November 2018. Perawat dikumpulkan di ruang rapat dan diberikan instruksi lisan oleh peneliti selama pengisian kuesioner. Pengisian kuesioner berjalan sekitar 5 - 10 menit. Pengumpulan data via online diawali dengan mengumpulkan daftar kontak dari perawat dan disortir berdasarkan latar belakang pendidikan dan tahun kelulusan supaya memenuhi karakteristik partisipan. Dari daftar perawat yang telah dipilih, peneliti mengirimkan pesan berisi penjelasan dan tautan ke kuesioner online via media komunikasi Whatsapp. Pengiriman pesan dilakukan dari tanggal 14 November 2018 hingga tanggal 30 November 2018. Selain itu, pesan berisi penjelasan dan tautan ke kuesioner online juga dipasang di beberapa media sosial. Total respon yang terkumpul adalah 145 respon, 3 respon diantaranya dianulir peneliti karena kesamaan identitas partisipannya sehingga hanya tercatat 142 partisipan via kuesioner online yang diproses datanya.

Data yang telah terkumpul dilakukan pengujian awal berupa pengujian model pengukuran dengan CFA dan pengujian kesesuaian model dengan program Lisrel 10.0. Setelah semua item diperiksa validitas dan reliabilitasnya, peneliti mengecek kesesuaian data lapangan dengan konstruk teoretis melalui uji awal model pengaruh variabel bebas terhadap variabel terikat. Dari data 178 partisipan didapatkan bahwa hubungan antara variabel bebas dan variabel terikat berkorelasi namun tidak signifikan. Rendahnya tingkat signifikansi dari model uji dibandingkan dengan teori dapat disebabkan karena terdapat perbedaan antara data yang dikumpulkan di lapangan dengan data ideal berdasarkan teori. Oleh karena itu, peneliti melakukan penajaman karakteristik sampel untuk menyaring data yang diperoleh dari lapangan dengan harapan partisipan yang dipilih dapat lebih menggambarkan model teoretis yang diuji.

Berdasarkan kondisi variabel ketidakseimbangan kehidupan-kerja, peneliti melakukan penajaman karakteristik sampel dari data penunjang kondisi tempat tinggal partisipan, dimana diasumsikan partisipan yang tinggal sendiri akan cenderung lebih tidak mengalami kondisi ketidakseimbangan kehidupan-kerja dibanding partisipan yang tinggal dengan keluarga. Berdasarkan kondisi tersebut, peneliti menggunakan data 120 partisipan yang berstatus tinggal dengan keluarga kemudian dilakukan pengujian model ulang dan diperoleh hasil korelasi yang signifikan (normed $\chi^{2}<2.00$, RMSEA $<0.05$ ). Hal tersebut menunjukkan bahwa terdapat kesesuaian antara hasil pengolahan data di lapangan dengan model secara teoretis setelah dilakukan penajaman karakteristik sampel. Oleh karena itu, pengolahan data selanjutnya peneliti 
menggunakan set data yang telah signifikan tersebut, yaitu set data dari 120 perawat yang tinggal dengan keluarga.

\section{Pengukuran penelitian}

Penelitian ini menggunakan bantuan kuesioner untuk pengumpulan data. Kuesioner yang digunakan dalam penelitian ini adalah Kuesioner UWES-9 (Utrecht Work Engagement Scale) untuk variabel keterikatan kerja, Industrial Society's Work-Life Checklist untuk variabel ketidakseimbangan kehidupan-kerja, dan Kuesioner CESS (Comprehensive Evaluation of Social Support) untuk variabel dukungan sosial.

Pengolahan data penelitian ini menggunakan metode SEM (Structural Equation Modeling), dengan kategori variabel valid bila $t$-value $\geq 1.96$ dan standardized loading factor $\geq 0.5$ (Gozali, 2008; Hair, 2009; Idulfilastri, 2018). Sementara pengujian reliabilitas konstruk berdasarkan Hair (2009) diharapkan dapat di atas 0.7. Keterikatan kerja diukur melalui kuesioner UWES-9 (Utrecht Work Engagement Scale) yang disusun oleh Wilmar Schaufeli dan Arnold Bakker (2002). Versi yang digunakan adalah versi singkat dengan total 9 item, mengukur tiga dimensi semangat (vigor), dedikasi (dedication), dan absorpsi (absorption). Partisipan memilih dari skor 0 (tidak pernah) hingga skor 5 (selalu). Contoh item dari UWES seperti "Di tempat kerja, saya merasa penuh energi." Dari total 9 item, 8 item telah valid (factor loading $=0.74-0.87$ ) dan reliabilitas tinggi (construct reliability $=0.988$ ). Ketidakseimbangan kehidupan-kerja diukur melalui kuesioner The Industrial Society's Work-Life Checklist yang disusun oleh Dex dan Bond (2005) yang telah diadaptasi. Jumlah item yang digunakan adalah 8 item valid dari total 10 item berskala likert (factor loading $=0.49-0.69$, construct reliability $=0.972$ ). Contoh item dari kuesioner ini seperti "Karena tuntutan pekerjaan, saya biasa bekerja melebihi shift kerja yang normal". Dukungan sosial diukur dengan alat ukur CESS (Comprehensive Evaluation of Social Support) yang disusun oleh Scott L. Boyar (2013). Dari 52 item awal, jumlah item valid yang digunakan adalah 46 item dengan pembagian berdasarkan 4 sumber dukungan (atasan, rekan kerja, organisasi, dan keluarga). Seluruh item disusun dalam skala likert dari nilai 0 (tidak pernah) hingga nilai 5 (selalu). Contoh item dari kuesioner ini seperti "Saya dapat mengandalkan ka.unit / ka.perawat untuk membantu pekerjaan saya." Pada dimensi supervisor, keseluruhan 12 item valid, dimensi coworker terdiri dari 9 item valid, dimensi organization terdiri dari 11 item valid, dan dimensi family terdiri dari 14 item valid. Keseluruhan dimensi memiliki reliabilitas yang tinggi (construct reliability $=0.987-0.990)$.

\section{HASIL DAN PEMBAHASAN}

Gambaran mengenai ketiga variabel penelitian ini dan dimensi-dimensinya diperoleh dengan mengolah data menggunakan analisis descriptive statistic dengan bantuan aplikasi SPSS Statistics 22. Seluruh item menggunakan skala likert dengan kontinum nilai minimal 0 hingga maksimal 5. Nilai median dari keseluruhan variabel dalam penelitian adalah sebesar 2.50. Rincian descriptive statistic dari keseluruhan variabel dan dimensi dapat dilihat pada tabel 1.

Tabel 1. Analisa descriptive statistic ketiga variabel

\begin{tabular}{lccccc}
\hline & Sig. & Min. & Max. & Mean & Std. Deviation \\
\hline Keterikatan Kerja & .000 & 1.75 & 5.00 & 4.1198 & .78262 \\
$\quad$ Vigor & .000 & 1.33 & 5.00 & 4.0528 & .85558 \\
$\quad$ Dedication & .000 & 1.00 & 5.00 & 4.1278 & .88158 \\
$\quad \begin{array}{l}\text { Absorption } \\
\text { Ketidakseimbangan }\end{array}$ & .000 & .00 & 5.00 & 4.2083 & .89015 \\
Kehidupan Kerja & .001 & .00 & 4.63 & 2.7885 & .93525 \\
Dukungan Sosial & .000 & 1.02 & 4.88 & 3.2536 & .77037 \\
$\quad$ Supervisor & .000 & .08 & 5.00 & 2.9444 & 1.04884
\end{tabular}




\begin{tabular}{lccccc} 
Coworker & .000 & .44 & 4.78 & 3.2556 & .86146 \\
Organization & .000 & .27 & 4.91 & 2.9583 & .99306 \\
Family & .000 & 2.00 & 5.00 & 3.8560 & .70309 \\
\hline
\end{tabular}

Rata-rata perawat memiliki keterikatan kerja yang tinggi $(\bar{x}=4.12)$. Perawat-perawat merasa penuh energi dan bersemangat di tempat kerja dan untuk mengerjakan pekerjaan keperawatan. Perawat-perawat juga merasa antusias dan bangga terhadap pekerjaannya, serta menikmati dan senang ketika dapat bekerja dengan sungguh-sungguh. Perawat secara signifikan merasa mengalami kondisi ketidakseimbangan kehidupan-kerja $(\bar{x}=2.79)$. Perawat menilai tuntutan pekerjaan mereka menyebabkan mereka biasanya bekerja melebihi shift kerja normal, kurang memiliki waktu berdiskusi dan bersosialisasi dengan keluarga dan teman-temannya, dan merasa sering terpikir serta perlu tetap siaga menangani urusan pekerjaan setelah pulang kerja.

Sementara pada variabel dukungan sosial, keempat dimensi dari dukungan sosial juga memiliki nilai rata-rata di atas 2.50, dengan dukungan tertinggi adalah dari dimensi $\operatorname{family}(\bar{x}=3.86)$ dan nilai terendah pada dimensi organization $(\bar{x}=2.96)$. Perawat mempersepsi memperoleh dukungan sosial yang tinggi. Perawat merasa atasan, rekan kerja, organisasi, dan keluarga sering memberikan perhatian dan kemudahan atas permasalahan-permasalahan yang dialaminya di tempat kerja ataupun terhadap permasalahan pribadinya.

Untuk melakukan pengujian hipotesis, maka dilakukan analisis structural model dengan SEM mengunakan bantuan Lisrel 10.0. Hasil pengolahan data menunjukkan bahwa ketidakseimbangan kehidupan-kerja memiliki pengaruh yang negatif terhadap keterikatan kerja $\left(\mathrm{r}=-0.24\right.$; normed $\chi^{2}<2.00$, RMSEA $<0.05$, t-value $\left.\geq 1.96\right)$. Setelah dilakukan interaksi antara variabel dukungan sosial sebagai variabel moderator, nilai korelasi ketidakseimbangan kehidupan kerja dan keterikatan kerja menjadi $\mathrm{r}=0.10(t$-value $<1.96)$. Dukungan sosial tidak berperan sebagai moderator bagi pengaruh negatif dari ketidakseimbangan kehidupan-kerja terhadap keterikatan kerja perawat.

Ketika diteliti pengaruh dari masing-masing dimensi sebagai variabel moderator, diperoleh hasil bahwa korelasi setelah berinteraksi dengan dimensi supervisor, organization, dan family adalah tidak signifikan ( $t$-value $<1.96)$, sementara interaksi dengan dimensi coworker menghasilkan hubungan antara ketidakseimbangan kehidupan-kerja dan keterikatan kerja yang positif dan signifikan $\left(\mathrm{r}=0.18, \quad t\right.$-value $\geq 1.96$, normed $\left.\chi^{2}<2.00, \quad \mathrm{RMSEA}<0.05\right)$. Dari keempat dimensi dukungan sosial, hanya dimensi coworker yang dapat memoderasi pengaruh negatif dari ketidakseimbangan kehidupan-kerja terhadap keterikatan kerja perawat, sementara dimensi supervisor, organization, dan family tidak menunjukkan peran moderasi yang signifikan.

Tabel 2. Pengujian korelasi dan peran moderasi

\begin{tabular}{lccccc}
\hline & $\begin{array}{c}\mathrm{r} \\
\text { (IV-DV) }\end{array}$ & Normed $\chi^{2}$ & t-value & RMSEA & Sig \\
\hline $\begin{array}{l}\text { Keterikatan Kerja }- \\
\text { Ketidakseimbangan }\end{array}$ & -0.24 & 1.97 & -2.00 & 0.000 & sig. \\
$\begin{array}{l}\text { Interaksi dengan } \\
\begin{array}{l}\text { Dukungan Sosial } \\
\text { (moderator) }\end{array}\end{array}$ & 0.10 & 4.05 & 1.26 & 0.000 & non-sig. \\
$\quad$ Supervisor & 0.09 & 3.43 & 1.08 & 0.000 & non-sig. \\
$\quad$ Coworker & 0.20 & 3.61 & 2.45 & 0.000 & sig. \\
$\quad$ Organization & 0.09 & 3.09 & 1.03 & 0.000 & non-sig. \\
$\quad$ Family & 0.06 & 4.07 & 0.74 & 0.000 & non-sig. \\
\hline
\end{tabular}


Hasil pengolahan data penelitian ini menunjukkan pengaruh antara kedua variabel tersebut adalah signifikan dan berkorelasi negatif, dimana hasil ini sejalan dengan penelitian yang dilakukan oleh Gabel-Sheumueli (2014) dan Virga (2015). Peranan moderator didasari oleh JD$\mathrm{R}$ model dengan asumsi bahwa dukungan sosial sebagai bentuk dari dukungan pekerjaan dapat memiliki efek buffer atau moderasi bagi hubungan ketidakseimbangan kehidupan-kerja dan keterikatan kerja perawat (Bakker, 2014; Xanthopoulou, 2013). Hasil dari pengolahan data dengan SEM menunjukkan bahwa dukungan sosial tidak secara signifikan menunjukkan peran moderasi, dimana menunjukkan perbedaan dengan JD-R model yang menjelaskan bahwa ketika karyawan dihadapkan pada kondisi tuntutan yang tinggi, dukungan sosial dapat menjadi semakin penting. Hasil penelitian juga menunjukkan perbedaan dengan penelitian dari Gabel-Shemueli (2012) bahwa dukungan pekerjaan berupa dukungan sosial, otonomi, dan kesempatan pengembangan diri signifikan memiliki efek buffer terhadap pengaruh dari tuntutan pekerjaan berupa beban kerja, tuntutan emosi, dan ketidakseimbangan keluarga-kerja terhadap keterikatan kerja secara umum pada perawat.

Hasil moderasi yang tidak signifikan diduga dapat terjadi karena dukungan sosial secara umum lebih memengaruhi ke motivasi individu daripada memengaruhi rintangan pekerjaan yang dialami (Montgomery, 2015; Bakker, 2014). Ketika dukungan yang diberikan tidak secara signifikan mengurangi kesulitan yang dialami akibat tuntutan pekerjaan, resource loss yang dialami perawat masih akan tetap berlanjut dan tetap menguras energi perawat. Motivasi yang timbul akibat dukungan-dukungan pekerjaan di satu sisi memotivasi perawat untuk semakin menyukai dan menikmati pekerjaannya, tetapi di sisi lain stres akibat tuntutan pekerjaan yang dialami perawat tidak berkurang. Ketika dukungan yang memotivasi tidak dapat mengimbangi besarnya energi yang hilang pada resources loss akibat tuntutan pekerjaan, perawat masih memiliki resiko yang besar mengalami kondisi stres dan burnout (Hobfoll, 2018). Penelitian dari Montgomery (2015) juga menunjukkan bahwa dibanding memoderasi pengaruh negatif terhadap keterikatan kerja, dukungan berupa kerjasama tim yang efektif lebih bersifat mengurangi burnout daripada meningkatkan keterikatan kerja, yang lebih jauh lagi membuktikan bahwa burnout dan keterikatan kerja bukan berada pada dua kutub yang kontinum.

Dimensi dukungan sosial dari supervisor, organization, dan family memiliki korelasi yang positif dan signifikan bila dihubungkan dengan keterikatan kerja secara langsung, tetapi sebagian besar tidak signifikan ketika adanya variabel moderator. Hal ini sejalan dengan dugaan peneliti bahwa dukungan sosial secara umum lebih memengaruhi ke motivasi individu daripada mengurangi pengaruh dari stres akibat tuntutan pekerjaan pada individu. Bila hanya melihat pengaruh masing-masing dimensi dukungan sosial terhadap keterikatan kerja, pengaruh yang signifikan juga telah teruji pada beberapa penelitian secara terpisah (Bakker, 2014; Chaudhary, 2014; Virga, 2015). Pengaruh dari dimensi-dimensi supervisor, organization, dan family lebih kepada memotivasi perawat untuk tetap memiliki semangat, dedikasi dan absorpsi yang tinggi daripada mengurangi efek negatif tuntutan pekerjaan terhadap keterikatan kerja.

\section{KESIMPULAN DAN SARAN}

Simpulan dari hasil penelitian ini adalah ketidakseimbangan kehidupan kerja memiliki pengaruh negatif yang signifikan terhadap keterikatan kerja perawat. Selain itu, dukungan sosial tidak menunjukkan peran yang signifikan sebagai moderator bagi pengaruh negatif dari ketidakseimbangan kehidupan-kerja terhadap keterikatan kerja pada perawat. Dari keempat dimensi dukungan sosial, hanya dimensi dukungan dari rekan kerja yang memiliki efek moderasi yang signifikan pada pengaruh negatif ketidakseimbangan kehidupan-kerja terhadap keterikatan 
kerja perawat, sementara dimensi supervisor, organization, dan family tidak memiliki peran moderasi yang signifikan.

Namun konsep dukungan sosial merupakan konsep yang cukup luas, dimana selain dilihat dari sumbernya, dukungan sosial juga dapat dilihat dari disposisi, evaluasi, sumber, arah, maupun konten. Oleh karena itu, disarankan pada penelitian berikutnya dapat lebih spesifik membedah variabel dukungan sosial dari beragam segi untuk memperoleh hasil yang lebih komprehensif. Peneliti juga menyarankan untuk penelitian berikutnya tidak hanya melihat keseimbangan kehidupan-kerja dari segi pekerjaan saja, tetapi juga dari tuntutan dari keluarga karena fenomena di lapangan banyak keseimbangan kehidupan-kerja dipengaruhi oleh pihak keluarga yang memberikan banyak tuntutan bagi kehidupan pribadi perawat.

\section{Ucapan terima kasih (Acknowledgement)}

Peneliti mengucapkan terima kasih kepada PT X yang telah memberi izin untuk melakukan pengambilan data secara langsung. Ucapan terima kasih ditujukan kepada pihak-pihak yang membantu pelaksanaan penelitian.

\section{REFERENSI}

Bakker, A. B., Albrecht, S. L., \& Leiter, M. P. (2011). Key questions regarding work engagement. European Journal of Work and Organizational Psychology, 20(1), 4-28. https://doi.org/10.1080/1359432X.2010.485352

Bakker, A. B., Demerouti, E., \& Sanz-Vergel, A. I. (2014). Burnout and work engagement: the JD-R Approach. Annual Review of Organizational Psychology and Organizational Behavior, 1(1), 389-411. https://doi.org/10.1146/annurev-orgpsych-031413-091235

Boyar, S. L., Campbell, N.S., Mosley Jr, D.C., Carson, C.M. (2014). Development of a work/family social support measure. Journal of Managerial Psychology, 29(7), 901-920, https://doi.org/10.1108/JMP-06-2012-0189

Chaudhary, R. (2014). A Multilevel investigation of the factors influencing work engagement. $\begin{array}{llll}\text { American Psychological } & \text { Association, } & 17(2), & 128-158 .\end{array}$ http://dx.doi.org/10.1037/mgr0000017

Dex, S., \& Bond, S. (2005). Measuring work-life balance and its covariates. Work, Employment and Society, 19(3), 627-637. https://doi.org/10.1177/0950017005055676

Gabel-Shemueli, R., Dolan, S., \& Ceretti A.S. (2012). Being engaged: the multiple interactions between job demands and job resources and its impact on nurses engagement. International Journal of Nursing, 3 (2), 17-32.

Gozali, I. (2008). Structural Equation Modeling: Teori, Konsep dan Aplikasi dengan Program LISREL 8.80 (edisi 2), Semarang: Badan Penerbit Universitas Diponegoro.

Greenhaus, J. \& Allen, T. D. (2011). Work-family balance: a review and extension of the literature. Handbook of Occupational Health Psychology, 2nd ed. (pp. 265-183). Washington, DC: American Psychological Association. https://doi.org/10.1680/udap.2010.163

Hair Jr., J.F., Black, W. C., Babin, B. J. \& Anderson, R. E. (2009) Multivariate data analysis (7 ${ }^{\text {th }}$ Ed.). Upper Saddle River: Prentice Hall

Hakanen, J. J., Bakker, A. B., \& Demerouti, E. (2005). How dentists cope with their job demands and stay engaged: the moderating role of job resources. European Journal of Oral Sciences, 113, 479-487. https://doi.org/10.1111/j.1600-0722.2005.00250.x 
Hobfoll, S. E., Halbesleben, J., Neveu, J., \& Westman, M. (2018). Conservation of Resources in the organizational context: The reality of resources and their consequences. The Annual Review of Organizational Psychology and Organizational Behavior, 5, 103-128. https://doi.org/https://doi.org/10.1146/annurev-orgpsych- 032117-104640

Hu, Q., Schaufeli, W. B., \& Taris, T.W. (2016). How are changes in exposure to job demands and job resources related to burnout and engagement? A longitudinal study among Chinese nurses and police officers. Stress and Health, 33, 631-644. doi: 10.1002/smi.2750

Idulfilastri, R.M. (2018). Pengujian konstruk tes potensi manajerial berdasarkan validitas butir dengan metode factor analysis. Jurnal Muara Ilmu Sosial, Humaniora, dan Seni, 2(1),189-197. https://journal.untar.ac.id/index.php/jmishumsen/article/view/1597/1167

Montgomery, A., Spanu, F., Baban A., \& Panagopoulou, E. (2015). Job demands, burnout, and engagement among nurses: A multi-level analysis of ORCAB data investigating the moderating effect of teamwork. Burnout Research, 2(2015), 71-79. http://dx.doi.org/10.1016/j.burn.2015.06.001

Ng, L.-P., Chen, I.-C., Ng, H.-F., Lin, B.-Y., \& Kuar, L.-S. (2017). Influence of job demands and job control on work-life balance among Taiwanese nurses. Journal of Nursing Management, 25(6), 438-448, . https://doi.org/10.1111/jonm.12482

Pratiwi, P. Y., Sintaasih, D. K., \& Piatrini, P. S. (2017). Stres kerja dan coping dalam memediasi konflik peran terhadap subjective well being. Ekuitas: Jurnal Ekonomi Dan Keuangan, 2(1), 1-21. https://doi.org/10.24034/j25485024.y

Runtu, V. V, Pondaag, L., \& Hamel, R. (2018). Hubungan beban kerja fisik dengan stres kerja kasih manado. E-Journal Keperawatan (EKp), 6(1), 1-7.

Schaufeli, W. B., Salanova, M., Gon Alez-ro, V. A., \& Bakker, A. B. (2002). The measurement of engagement and burnout: a two-sample confirmatory factor analytic approach. Journal of Happiness Studies, 3, 71-92. https://doi.org/10.1023/A:1015630930326

Schaufeli, W.B., Bakker, A.B. Salanova, M. (2006). The measurement of work engagement with a short questionnaire: a cross-national study. Educational and Psychological Measurement, 66(4), 701-716. doi: 10.1177/0013164405282471

Siwu, M. F. S., Pinontoan, O., \& Rumayar, A. A. (2018). Hubungan antara masa kerja dan beban kerja dengan stres kerja pada perawat di ruang rawat inap Rumah Sakit Umum Bethesda GMIM Tomohon. Kesmas E-journal, 7(2), 1-8.

Virga, D., Horga, A., \& Iliescu, D. (2015). Work-life imbalance as a moderator in the relationship between resources and work engagement. Journal of Personnel Psychology, 14(2), 80-90. https://doi.org/10.1027/1866-5888/a000135

Widhiarso, W. (2010). Jumlah sampel dalam pemodelan persamaan struktural (SEM). November 27, 2018. http://widhiarso.staff.ugm.ac.id/files/widhiarso_2010__jumlah_sampel_dalam_pemodelan_persamaan_struktural_sem_.pdf 